Y.L. Anokhin, V.O. Brzhezytskyi, Ya.O. Haran, I.M. Masliuchenko, O.P. Protsenko, Ye.O. Trotsenko

\title{
APPLICATION OF HIGH VOLTAGE DIVIDERS FOR POWER QUALITY INDICES MEASUREMENT
}

Introduction. Determination of power quality indices in high-voltage power grids allows to find the reasons for the deterioration of the power quality. The relevant national and International Standards for power quality contain relevant norms of quality indices and requirements for their accuracy measurement. Problem. The most complicated part in the process of measuring the power quality indices at high voltage is the selection of the corresponding high-voltage scale voltage converters. Therefore, comparing the requirements of IEC 61000-4-30 to high voltage scale voltage converters is an important task. Goal. Analysis of the International Standard IEC 61000-4-30 requirements feasibility for measuring the indices of power quality in high-voltage electrical networks using different types of high-voltage scale voltage converters. Methodology. Comparison of the requirements of IEC 61000-4-30 Standard to high-voltage scale voltage converters, when measuring power quality indices, with the characteristics of high voltage electromagnetic transformers used in Ukraine, and with promising developments of high-voltage converters of other types. Results. It is shown in the study that in order to fulfill some of the requirements for class $A$ of IEC 61000-4-30, the characteristics of electromagnetic voltage transformers should be determined in the substation conditions using mobile calibration high-voltage laboratories. To meet all the requirements for Class A IEC 61000-4-30, it is recommended to use broadband high-voltage dividers of resistive-capacitive type. Originality. In study it is shown firstly that all the requirements of the IEC 61000-4-30 Standard for high-voltage scale voltage converters can be performed on the basis of the use of broadband resistive-capacitive damped voltage dividers. Practical value. Expositions of specific types of resistive-capacitive high-voltage dividers are presented, their parameters are confirmed by the results of state metrological certification. References 17 , figures 11. Key words: power quality indices, high voltage, electromagnetic transformers, voltage dividers.

Цель. Анализ выполнимости требований мељљународного стандарта ІЕС 61000-4-30 при измерениях показателей качества электроэнергии в высоковольтных электрических сетях с использованием различных типов высоковольтных маситабных преобразователей напряжения. Методика. Сравнение требований стандарта ІЕС 61000-4-30 к высоковольтным масштабным преобразователям напряжения, при измерении показателей качества электроэнергии, с характеристиками электромагнитных трансформаторов высокого напряэения, применяемых в Украине, и с перспективными разработками масштабных преобразователей высокого напряжения других типов. Результаты. Показано, что для выполнения части требований по классу А ІЕС 61000-4-30 характеристики электромагнитных трансформаторов напряжения должны быть определены в условиях подстанции с помощью мобильных поверочных высоковольтных лабораторий. Для выполнения всех требований по классу А IEC 61000-4-30 рекомендуется использование высоковольтных широкополосных делителей напряжения емкостно-омического типа. Научная новизна. Впервые показано, что все требования стандарта ІЕС 61000-4-30 к высоковольтным масштабным преобразователям напряжения могут быть выполнены на основе использования иирокополосных емкостноомических демпфированных делителей напряжения. Практическая значимость. Представлены экспозиции конкретных типов емкостно-омических делителей высокого напряжения, их параметры, подтвержденные результатами государственной метрологической аттестации. Библ. 17, рис. 11.

Ключевые слова: показатели качества электроэнергии, высокое напряжение, электромагнитные трансформаторы, делители напряжения.

Introduction. The transition to free market economy in the electric power industry of Ukraine in accordance with the recently adopted the Electricity Market Law, as well as the prospect of joining the Ukrainian energy system to the European Union energy system, posed a serious problem of increasing the domestic power quality (PQ) level to the requirements of European Standards. At the same time, this problem is technically divided into two parts: first, it is necessary to create means for measuring power quality indices and perform their metrological certification, and then, using these tools, to improve the power quality at specific power facilities. To reduce the loss of time, it is advisable to perform both tasks in parallel.

It should be noted that, in fact, the power quality at a particular site (at a certain point of connection) is determined only by the voltage characteristics [1], but in order to detect sources of deterioration in the power quality, it is also necessary to have information on the characteristics of the current consumed by the loads connected to this point [2].
In accordance with [1], the power quality indices are normalized for low-voltage networks (for example, $220 / 380 \mathrm{~V}$ ), as well as for voltage classes of $6-20 \mathrm{kV}$; $35 \mathrm{kV} ; 110-330 \mathrm{kV}$ and separately $500-750 \mathrm{kV}$.

In accordance with [3], the power quality indices (PQI) are normalized for voltages up to $150 \mathrm{kV}$, inclusive, while according to [4] - up to $220 \mathrm{kV}$. For higher voltage classes, the power quality indices are determined based on the contractual relationship between the supplier and the consumer of electricity.

For low-voltage electrical networks in a number of countries (Israel, Germany, Japan and others), firms produce certified (by the international organizations) means of measuring the power quality indices (MM PQI) adapted to certain power quality standards, with a range of input nominal voltages, for example $100 / \sqrt{ } 3 \mathrm{~V}, 100 \mathrm{~V}$, $110 \mathrm{~V}, 220 \mathrm{~V}, 230 \mathrm{~V}$, and so on. [5]. For high-voltage electrical networks, these devices are connected to the outputs of high-voltage measuring transducers [2], among which the most requested are high-voltage measuring electromagnetic voltage transformers and voltage dividers

(C) Y.L. Anokhin, V.O. Brzhezytskyi, Ya.O. Haran, I.M. Masliuchenko, O.P. Protsenko, Ye.O. Trotsenko 
(current converters intended for the purposes of power quality measurements are not reviewed in this paper).

The feature of the Standards, regulating methods and means of measuring power quality indices $[2,6]$ is that they establish general requirements for such facilities, and the one who conducts the measurement of power quality indices should select the type of MM PQI. In the existing high-voltage electrical networks, the measurement of PQI is carried out using high-voltage transformers involved in substation circuits (of НОМ, ЗНОМ, НАМИ, НКФ, НОГ types) that do not meet all requirements for large-scale voltage converters for measuring power quality $[2,6]$. As a result, they get knowingly «improved» power quality indices that are not true. Unfortunately, this problem has not been systematically studied in the domestic literature.

In foreign publications attention is paid to the problem of measuring power quality in high-voltage systems. For example, in [7] it is noted that if earlier the main problem was power supply interruptions, nowadays the main thing is the quality of electric power, the registration of the power quality indices, while the use of voltage dividers is the preferred one in the role of highvoltage converters.

The paper [8] describes the circuit and design of the divider for a $400 \mathrm{kV}$ network, which, although called a «resistive» voltage divider, is in fact is a resistivecapacitive voltage divider with parallel connection of $R$, $C$ - elements. Its purpose is to measure harmonics in a 400 $\mathrm{kV}$ network. The height of the divider is $3.78 \mathrm{~m}$, the maximum diameter of anti-corona ring is $2.0 \mathrm{~m}$.

The work [9] compares the results of measurements of voltage harmonics in a $400 \mathrm{kV}$ network using a divider and voltage transformers. As a result of the measurement it is shown that the total ratio of higher harmonic components of voltage for the resistive divider and the electromagnetic voltage transformer practically coincide, while for the capacitive voltage transformer dramatically different results are obtained.

In [10], the development of a pulse resistive voltage divider is described for recording a lightning impulse up to $500 \mathrm{kV}$. The height of the divider is $1.84 \mathrm{~m}$ with maximum diameter of the anti-corona ring of $0.96 \mathrm{~m}$. The resistance of the high-voltage arm of the voltage divider is $10.3 \mathrm{k} \Omega$.

Low-voltage experimental studies of the frequency characteristics of a pulsed resistive voltage divider with nominal voltage of up to $1000 \mathrm{kV}$ and a resistivecapacitive divider with nominal voltage of up to $200 \mathrm{kV}$ have been carried out in [11]. Measurements were also made of the reaction time of the dividers by the stepped pulse method, while the first divider reaction time was 47 ns and the second one was $120 \mathrm{~ns}$.

According to the results of the review of foreign publications, it can be concluded that high-voltage dividers are considered as a promising alternative to electromagnetic voltage transformers when measuring power quality in high-voltage systems. In this case, resistive-capacitive voltage dividers have similar dynamic characteristics with impulse resistive dividers.

The goal of the paper. On the basis of the analysis of the requirements for means of measuring the power quality parameters $[2,6]$, to justify the necessity of using voltage dividers in high-voltage systems for measuring these indices, and also to generalize the results of studies of high-voltage broadband voltage dividers made at the Department of High Voltage Engineering and Electrophysics of the National Technical University of Ukraine «Igor Sikorsky Kyiv Polytechnic Institute» (HVEE of NTUU «KPI»). At the same time, high voltages will be understood as voltages whose nominal values are $110 \mathrm{kV}, 150 \mathrm{kV}$ [3] and $220 \mathrm{kV}$ [4]. The requirements for the measurement parameters will be assigned to class $\mathrm{A}$, since it is a question of the correspondence of the real power quality to the requirements of International Standards $[2,3,6]$.

Below we will analyze only those indices that affect the use of high-voltage measuring transducers in determining the power quality in high-voltage networks.

The root-mean-square value of the voltage in accordance with 5.2.1 [2] must take into account the harmonics, interharmonics, telecontrol signals existing in the electrical network. Its measurement uncertainty in accordance with 5.2.2 [2] should not exceed $\pm 0.1 \%$ of the voltage $U_{\text {din }}$ (declared input voltage) in the range of 10 $150 \%$ of $U_{\text {din }}$, with the range of disturbances according to Table C.1 [2] is $10-200 \%$ of $U_{d i n}$.

Electromagnetic voltage transformers (types НКФ 110, НКФ - 150, НКФ - 220, НОГ 110 - 220) used in most cases at electric stations and substations in accordance with the Interstate Standard [12] are capable of withstanding in the course of 1 s $200 \%$ overvoltage of frequency of $50 \mathrm{~Hz}$, but the guaranteed area of their accuracy class $(0.2 ; 0.5)$ corresponds only to the range of $80-120 \%$ of the nominal voltage.

Concerning the permissible uncertainty in the measurement of $\pm 0.1 \% U_{\text {din }}$, it should be noted that the Department of HVEE of NTUU «KPI» created a mobile calibration laboratory [13] of classes 6-110 kV (Fig. 1) the use of which makes it possible to determine the tolerance of voltage transformers in substations at their actual load, and thus, taking into account the introduction of the corresponding adjustment, to reduce the uncertainty of $U_{\text {din }}$ measurement to $\pm 0.03 \%$.

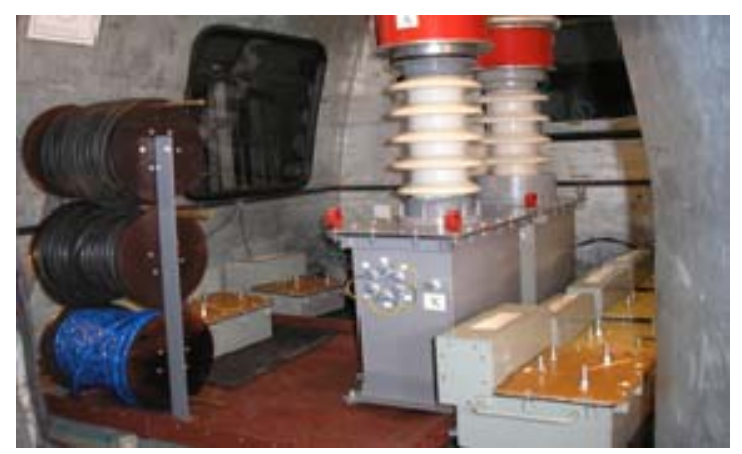

Fig. 1. A mobile calibration laboratory for classes $6-110 \mathrm{kV}$

However, taking into account the fact that «electromagnetic voltage transducers of transformer type have frequency and transient characteristics that are applicable for operation at frequencies up to $1 \mathrm{kHz})$ (cited from [2]), their use for measurements of higher harmonics and interharmonics with order $n>20$ ( and, moreover, the 
telecontrol signals) are unreasonable. Thus, high voltage electromagnetic voltage transformers used in electric stations and substations do not meet the requirements for determining the rms voltage value in class A [2].

Voltage of harmonics and interharmonics. In accordance with the above definition [2], electromagnetic voltage transformers are not suitable for an adequate scale conversion of harmonics and interharmonics, with an order that exceeds 20 .

The voltage asymmetry is determined by the main voltage harmonics in three-phase networks [2, 6], which are transformed with sufficient accuracy by electromagnetic voltage transformers (subject to corrections, determined using a mobile calibration laboratory [13]). Existing devices for measuring power quality indices [5], as a rule, determine the line voltages with sufficient accuracy when using the results of measuring phase voltages.

The above power quality indices are related to quasistatic modes of three-phase systems. Other indices, such as flicker, voltage dips and rises, short-term voltage interruptions, telecontrol signals in electrical networks, voltage of transients and fast transients refer to the dynamic modes in three-phase electrical systems whose scale voltage transformation is not provided by existing high-voltage electromagnetic voltage transformers, since the characteristic value of their time constant is $10-400 \mathrm{~ms}$ [14]. In this connection, it can be concluded that a full-scale measurement of power quality indices in high-voltage systems should be carried out using high-voltage measuring dividers. Using the electromagnetic voltage transformers used in high-voltage electrical networks, it is possible to measure the asymmetry of voltages as well as voltage interruptions.

The choice of types of high-voltage dividers for the purposes of measuring the power quality indices has its own specific solution. The Standard [2] states that: «... capacitive dividers may have frequency and phase characteristics, used to operate at frequencies up to hundreds of kilohertz or higher; but in many applications a resonant circuit is added, which makes the frequency response of the capacitive divider inapplicable for measurements at any frequency other than resonant.» The latter refers to the so-called capacitive high-voltage transformers. Therefore, in the above-mentioned publication [9] it is noted that the results of measuring the total coefficient of higher harmonic components for voltage of $400 \mathrm{kV}$ using a capacitive voltage transformer are unacceptable. Similar measurement results for a resistive voltage divider and an electromagnetic voltage transformer are similar [9]. This is because the harmonics with the order $n \leq 20$ are satisfactorily transformed $[2,6]$ by electromagnetic voltage transformers, which explains the agreement of the results of measuring the total coefficient of higher harmonic voltage components for the «resistive» divider and the electromagnetic voltage transformer [9].

At the same time, as noted above, the «resistive» voltage divider [9] is actually (according to the circuit) a resistive-capacitive voltage divider with a parallel-series connection of $R, C$ - elements. "Resistive voltage dividers can have frequency and phase characteristics that allow operation at frequencies up to hundreds of kilohertz. However, they can introduce other problems, for example, the capacitive nature of the load of the measuring device can affect the frequency and phase characteristics of the voltage divider» (quoted by $[2,6]$ ). With respect to the above provisions $[2,6]$, it should be noted that the only correct solution for the type of high-voltage divider for PQI measurements in high-voltage systems is the combination of a resistive and capacitive divider, i.e. the use of a resistive-capacitive voltage divider, as in [9] (the authors' development on this issue will be considered below). This allows, in principle, to ensure the constant amplitude-frequency response (AFR) of the voltage divider from zero to the high-frequency region with «zero» values of the phase-frequency response of the divider in the same frequency range. This solution also makes it possible to remove the question of the effect of the capacitive load of the measuring device on the coefficient of conversion of the voltage divider.

Developments of the Department for High Voltage Engineering and Electrophysics of the NTUU «Igor Sikorsky Kyiv Polytechnic Institute» in the field of research of high-voltage dividers. The task of developing a high voltage divider for the measurement of the PQI is to create a so-called wideband voltage divider whose dividing ratio would be constant (within $\pm 0.1 \%$ of the nominal value) up to frequency of $10 \mathrm{MHz}$. Although resistive-capacitive dividers with a parallel-series connection of $R, C$ - elements are principally designed for this, however, a number of complex phenomena arise in their implementation.

1. The instability of the amplitude-frequency response caused by the nonidentity of the values of the $R, C$-elements of the high-voltage arm of the voltage divider (VD). If we present the circuit of a high-voltage resistive-capacitive voltage divider (of a mixed type) in the form (Fig. 2), it can be shown [15] that for the amplitude-frequency response (AFR) and the phasefrequency response (PFR) of the divider, the following expressions can be obtained:

$$
\begin{aligned}
& A F R=\frac{1}{K} A^{*}, \\
& A^{*}=\sqrt{\frac{\left(1+\frac{K-1}{K} f\right)^{2}+\gamma^{2}\left(1+\frac{K-1}{K} \delta\right)^{2}}{\left(\frac{1+\gamma^{2}}{K}\right.},} \\
& P F R=\operatorname{arctg}\left(\frac{(\delta-f) \gamma}{f+\frac{K}{K-1}+\gamma^{2}\left(\delta+\frac{K}{K-1}\right)}\right)
\end{aligned}
$$

where $K$ is the nominal value of the division coefficient of the VD, at which the parameters of the low-voltage arm are determined in the form

$$
\begin{gathered}
r=\frac{n R_{0}}{K-1}, \quad c=\frac{C_{0}}{n}(K-1), \\
R_{0}=\frac{1}{n} \sum_{i=1}^{n} R_{i}, \quad C_{0}=\frac{1}{n} \sum_{i=1}^{n} C_{i}, \quad \gamma=\omega R_{0} C_{0}
\end{gathered}
$$


(the dimensionless angular frequency parameter), and the parameters $f=\frac{1}{n} \sum_{i=1}^{n} D_{i}, \quad \delta=\frac{1}{n} \sum_{i=1}^{n} G_{i}$ take into account the functions of the nonidentity of its elements averaged over the elements of the high-voltage arm $\alpha_{i}=\frac{C_{i}-C_{0}}{C_{0}}$, $\beta_{i}=\frac{R_{i}-R_{0}}{R_{0}}$ in the form of the following formulae

$$
\begin{gathered}
D_{i}=\frac{\gamma^{2}\left(T_{i}+\gamma^{2} S_{i}\right)}{\left(1+\gamma^{2}\right) \cdot\left[1+\gamma^{2}\left(1+\beta_{i}\right)^{2}\left(1+\alpha_{i}\right)^{2}\right]}, \\
G_{i}=\frac{\beta_{i}+2 \alpha_{i} \beta_{\dot{i}}+\alpha_{i} \beta_{i}^{2}+\gamma^{2}\left(P_{i}+\gamma^{2} Q_{\dot{j}}\right)}{\left(1+\gamma^{2}\right) \cdot\left[1+\gamma^{2}\left(1+\beta_{i}\right)^{2}\left(1+\alpha_{i}\right)^{2}\right]},
\end{gathered}
$$

and here

$$
\begin{aligned}
& Q_{i}=\alpha_{i}^{2}\left(1+\alpha_{i}\right)\left(1+\beta_{i}\right)^{2}, \\
& T_{i}=-\left(\begin{array}{l}
6 \alpha_{i} \beta_{i}+6 \alpha_{i} \beta_{i}^{2}+2 \alpha_{i} \beta_{i}^{3}+\alpha_{i}^{2}+3 \alpha_{i}^{2} \beta_{i}+ \\
+3 \alpha_{i}^{2} \beta_{i}^{2}+\alpha_{i}^{2} \beta_{i}^{3}+3 \beta_{i}^{2}+\beta_{i}^{3}
\end{array}\right), \\
& S_{i}=2 \alpha_{i} \beta_{i}+4 \alpha_{i} \beta_{i}{ }^{2}+2 \alpha_{i} \beta_{i}{ }^{3}+3 \alpha_{i}{ }^{2}+7 \alpha_{i}{ }^{2} \beta_{i}+\alpha_{i}{ }^{2} \beta_{i}{ }^{3}+ \\
& +5 \alpha_{i}^{2} \beta_{i}^{2}+2 \alpha_{i}^{3}+4 \alpha_{i}^{3} \beta_{i}+2 \alpha_{i}^{3} \beta_{i}^{2}+\beta_{i}^{2}+\beta_{i}^{3} \\
& P_{i}=-\left(\begin{array}{l}
6 \alpha_{i} \beta_{i}+9 \alpha_{i} \beta_{i}^{2}+4 \alpha_{i} \beta_{i}^{3}+3 \alpha_{i}^{2}+8 \alpha_{i}^{2} \beta_{i}+ \\
+7 \alpha_{i}^{2} \beta_{i}^{2}+2 \alpha_{i}^{2} \beta_{i}^{3}+\alpha_{i}^{3}+2 \alpha_{i}^{3} \beta_{i}+ \\
+\alpha_{i}^{3} \beta_{i}^{2}+3 \beta_{i}^{2}+2 \beta_{i}^{3}
\end{array}\right) .
\end{aligned}
$$

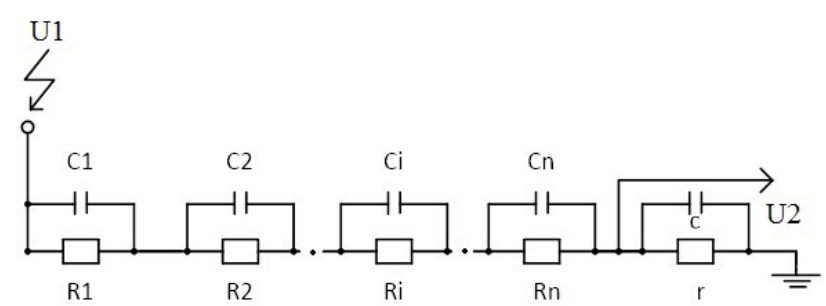

Fig. 2. The circuit of a high-voltage divider of mixed type according to [15] (here $R_{i}, C_{i}$ are the values of resistances and capacitances of the elements of the high-voltage divider arm,

$r, c$ are the values of the elements of its low-voltage arm)

It should be noted that expressions (1)-(5) were obtained [15] in the general case, without assuming the smallness of the parameters $\alpha_{i}, \beta_{i}, \gamma$. In the absence of nonidentity of $R_{i}, C_{i}$ elements, i.e. $R_{1}=R_{2}=\ldots=R_{i}=\ldots=R_{n}$, $C_{1}=C_{2}=\ldots=C_{i}=\ldots=C_{n}, \alpha_{i} \equiv 0, \beta_{i} \equiv 0$ and from (4), (5) we obtain $f \equiv 0, \delta \equiv 0$ and, accordingly, $A^{*}=1$ and $P F R \equiv 0$.

In [16], the work [15] was further developed taking into account the assumption of the «triangular» law of the probability distribution of the deviation of the parameters $\alpha_{i}, \beta_{i}$ from the zero value, see Fig. $3 *$ ).

Below, according to the data of [16], the dependence of the deviation of the normalized value of the amplitudefrequency response $\left(A^{*}-1\right) \cdot 100 \%$, in $\%$ and PFR (') in angular minutes for mixed type VD on the dimensionless frequency parameter $\lg (\gamma)$ is presented (see Fig. 4, 5).

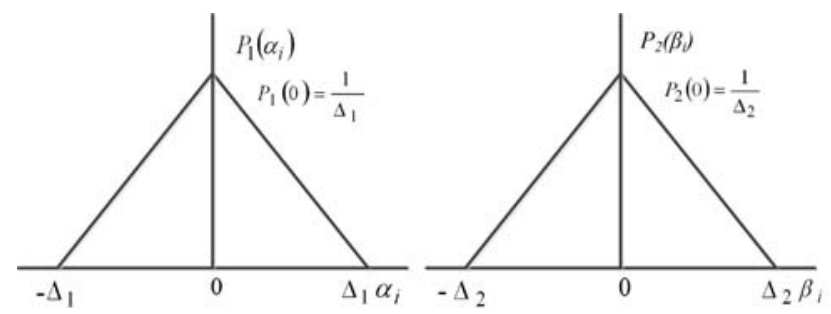

Fig. 3. The graph of the «triangular» probability distribution $P_{l}\left(\alpha_{i}\right)$ and $P_{2}\left(\beta_{i}\right)$

*Note: Since the number of elements of the high-voltage arm of the VD is usually $n>>100$, it is advisable to switch to the use of the distribution functions $P_{l}\left(\alpha_{i}\right), P_{2}\left(\beta_{i}\right)$

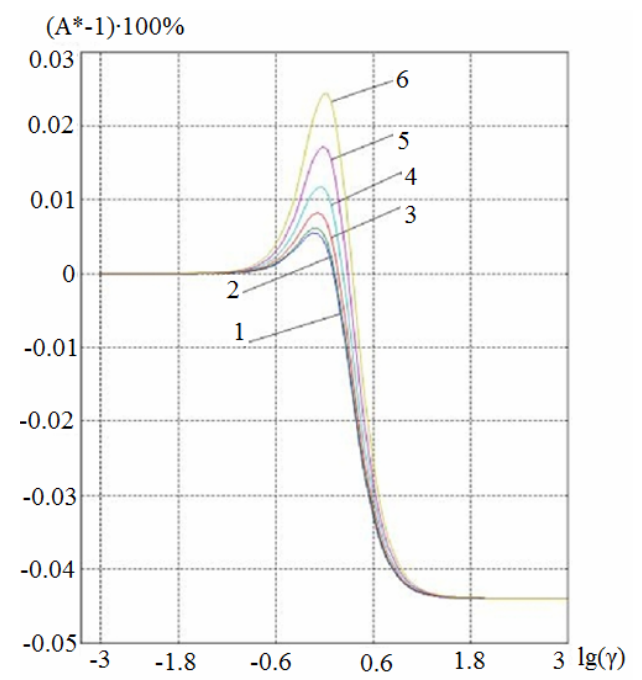

Fig. 4. Dependence $\left(A^{*}-1\right) \cdot 100 \%$ for mixed type VD depending on the dimensionless frequency parameter $\gamma$ for fixed $\Delta_{1}=0.05$ when the value of $\Delta_{2}$ is changed in the range: $0.00 \ldots 0.05$, here the designation 1 corresponds to $\Delta_{2}=0.00$; the designation 2 corresponds to $\Delta_{2}=0.01$; the designation 3 corresponds to $\Delta_{2}=0.02$; the designation 4 corresponds to $\Delta_{2}=0.03$; the designation 5 corresponds to $\Delta_{2}=0.04$; the designation 6 corresponds to $\Delta_{2}=0.05$

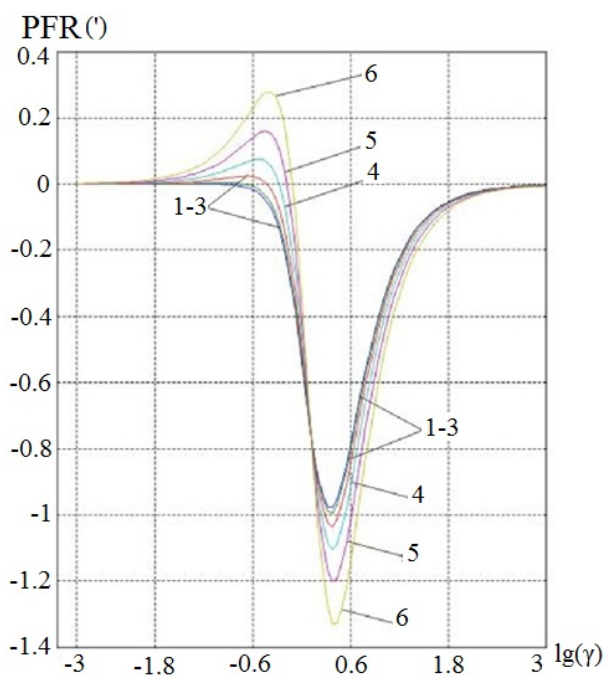

Fig. 5. Phase-frequency response for mixed type VD depending on the dimensionless frequency parameter $\gamma$ for fixed $\Delta_{1}=0.05$ when the value of $\Delta_{2}$ is changed in the range: $0.00 \ldots 0.05$, here the designation 1 corresponds to $\Delta_{2}=0.00$; the designation 2 corresponds to $\Delta_{2}=0.01$; the designation 3 corresponds to $\Delta_{2}=0.02$; the designation 4 corresponds to $\Delta_{2}=0.03$; the designation 5 corresponds to $\Delta_{2}=0.04$; the designation 6 corresponds to $\Delta_{2}=0.05$ 
From the data in Fig. 4, 5 and [16], we can draw conclusions:

- the influence of non-identity - the «scatter» of the values of the elements $\left(R_{i}, C_{i}\right)$ of the high-voltage arm of a mixed VD leads to instability of its frequency characteristics;

- the influence of the boundaries of the «spread» of the active elements of the high-voltage arm up to $\Delta_{2}=0.01( \pm 1 \%)$ is negligible compared to the effect of a «spread» of capacitive elements with a level $\Delta_{1}=0,05( \pm 5 \%)$. The «spread» of the capacitance values of the high-voltage arm of the VD $( \pm 5 \%)$ is still acceptable, since it leads to a range of AFR oscillations of up to $0.05 \%$;

- the influence of the «spread» of capacitive elements on the frequency characteristics is proportional to the square of the values of its boundaries $\left(\sim \Delta_{1}^{2}\right)$;

- PFR instability of mixed type VD caused by the nonidentity of its $R_{i}, C_{i}$ elements of the high-voltage arm up to $\Delta_{1}=0.05 ; \Delta_{2}=0.01$, is negligible.

2. Dependence of the scale factor of the highvoltage divider on its input voltage level.

As already stated above, the tolerance of high voltage electromagnetic voltage transformers is normalized for a range of $80-120 \%$ of their rated voltage [13], which is due to nonlinear magnetization of their magnetic circuit. For high-voltage dividers of mixed type, this dependence can be significantly weakened when the potential distribution along the internal circuit of the lumped $R, C$ - elements of the high-voltage arm (Fig. 2) is consistent with the distribution of the potential in the spatial-field circuit of the divider due to the electric field between its high-voltage and grounded electrodes.

Fig. 6, 7 show the dependences of the tolerance of the high-voltage divider of the «high-voltage meter of direct and alternating voltage $\mathrm{BBH}-0,8-100 \mathrm{M} »$, developed by the Department of HVEE of NTUU «KPI» (Fig. 8) according to its state metrological attestation at the State Enterprise «Ukrmetrteststandart» (Kyiv) processed in [17]. The tolerance of the high-voltage divider was determined as $\Delta=\frac{K_{n}-K_{m}}{K_{n}} \cdot 100 \%$, where $K_{n}$ is the nominal value of the divider dividing ratio (in this case $K_{n}=10000$ ), and $K_{m}$ is its actual value, determined by the ratio of the rms values of the input and output voltages, averaged over the results of 10 independent observations. The load of the divider was on the active resistance $(10 \pm 0.5) \mathrm{M} \Omega$, on capacitance $(10 \pm 5) \mathrm{pF}$.

The difference between the dependences 1 and 2 of the tolerance of high-voltage dividers in Fig. 5, 6 is explained by the appearance in the first case of a microcoron on its $R, C$ - elements, which leads to leakage of the current of the high-voltage arm with an increase in the input voltage of the divider, while the actual value of its division factor $K_{m}$ increases. Thus, it is obligatory to reconcile the distribution of the potentials of the circuit of lumped $R, C$-elements and the spatial-field circuit of the divider. In this case, the range of oscillations in the tolerance of the voltage divider in the range $10-100 \mathrm{kV}$ will be an acceptable value of $\pm 0.1 \%$.

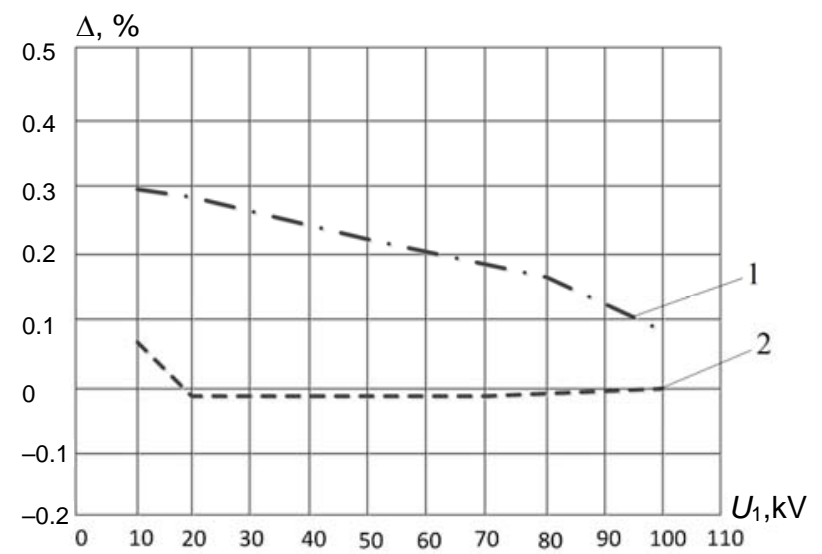

Fig. 6. The experimental dependence of the tolerance of the same voltage dividers of the high voltage meter $\mathrm{BBH}-0,8-$ $100 \mathrm{M}$ in the range of the input DC voltage variation $10 \ldots 100$

$\mathrm{kV}: 1$ - design of the high-voltage arm with a uniform arrangement of $R, C$ - elements in the height of the divider; 2 design of a high-voltage arm with a coordinated distribution of potentials of the internal circuit with lumped $R, C$ - elements and the spatial-field circuit of the divider.

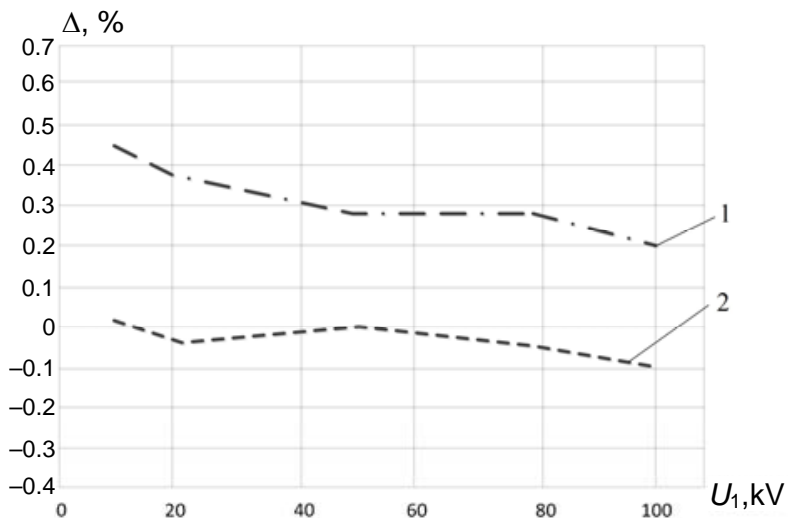

Fig. 7. The experimental dependence of the tolerance of the same voltage dividers of the high voltage meter BBH- $0,8-100 \mathrm{M}$ in the range of the input $\mathrm{AC}$ voltage variation $10 \ldots 100 \mathrm{kV}$

(frequency $50 \mathrm{~Hz}$ ): 1 - design of the high-voltage arm with a uniform arrangement of $R, C$ - elements in the height of the divider; 2 - design of a high-voltage arm with a coordinated distribution of potentials of the internal circuit with lumped $R, C$ - elements and the spatial-field circuit of the divider.

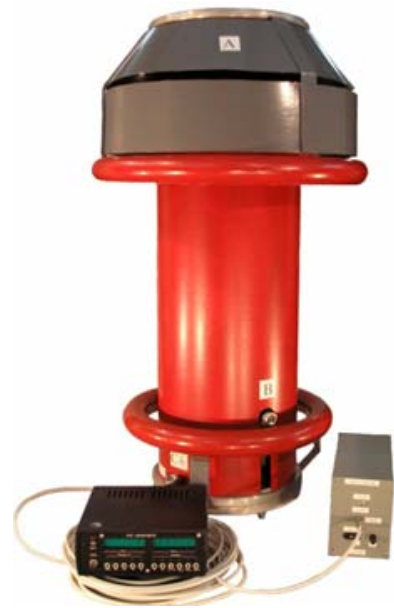

Fig. 8. General view of the set for measuring high voltage BBH-0,8-100M in the composition of a high-voltage arm, a low-voltage arm, a specialized digital voltmeter and connecting cables. The separate design of the low-voltage divider arm is due to the possibility of its adjustment and switching for the high-voltage measuring ranges $0.8-10 \mathrm{kV}$ and $10-100 \mathrm{kV}$ 


\section{Features of broadband voltage dividers for the} high frequency region, as well as for measuring pulse voltages. In this case, the low-voltage divider arm should have a low-inductance design and must be built into the overall design of the divider. In addition, it is necessary to use damping resistances in the circuits of the high-voltage and low-voltage divider arms, as well as the matching resistances in the cable connection of the oscilloscope, Fig. 9.

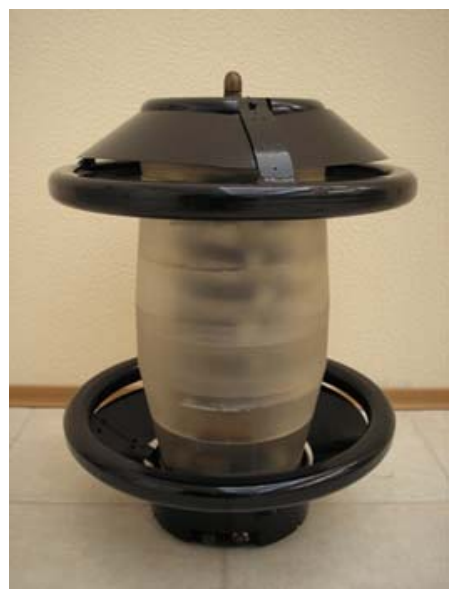

Fig. 9. External view of a high-voltage broadband voltage divider ВДН -75 designed to measure $\mathrm{DC}, \mathrm{AC}$ and pulse voltages of $110 \mathrm{kV}$ class (the nominal value of the division factor is $K_{n}=10000$ )

Fig. 10 shows an oscillogram of the output voltage of ВДН - 75 when a step voltage pulse is applied to its input.

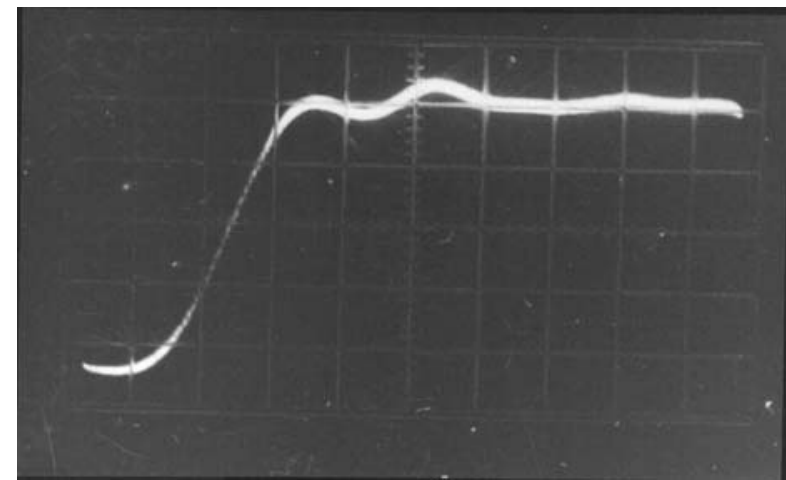

Fig. 10. Output voltage oscillogram of a high-voltage wideband divider ВДН - 75 when a step voltage pulse is applied to its input (vertical scale is $10 \mathrm{mV}$ per division, horizontal scale is $20 \mathrm{~ns}$ per division)

Processing of this oscillogram according to the requirements of the Standard IEC 60060-2 determines the response time of the ВДН -75 divider $\tau_{r} \sim 25 \cdot 10^{-9} \mathrm{~s}$, which allows it to be used for measurement of switching, lightning, and chopped lightning voltage impulses.

Fig. 11 is a general view of the voltage divider of the $220 \mathrm{kV}$ class for measuring the power quality indices in $220 \mathrm{kV}$ electric networks developed by the Department of HVEE of NTUU «KPI» under a contract with State Enterprise «NEC Ukrenergo».

To test high-voltage voltage dividers in substation conditions, it is advisable to develop the capabilities of high-voltage mobile calibration laboratories [13] for metrological certification, both transformers and voltage dividers with their actual load.

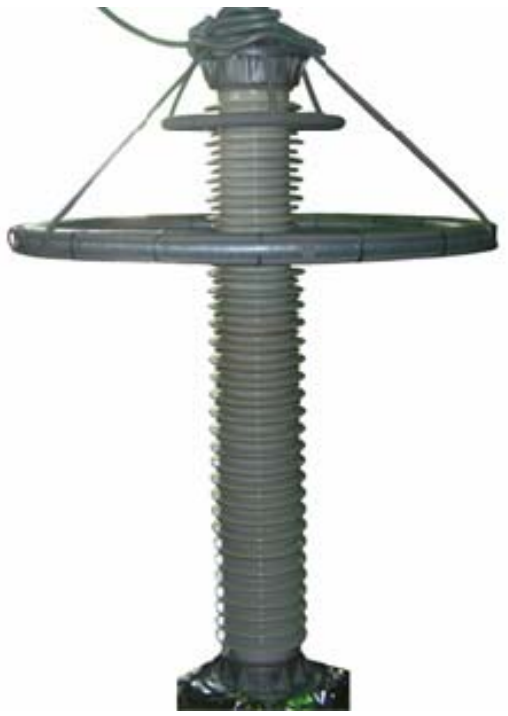

Fig. 11. A high-voltage divider class $220 \mathrm{kV}$ for measuring the power quality indices (outdoor design)

\section{Conclusions.}

1. In accordance with the requirements of the International Standard IEC 61000-4-30, electromagnetic voltage transformers used in substations can be used to measure such high-voltage power quality indices as voltage asymmetry and voltage interruption (tripping), provided they are metrologically certified on site using mobile calibration laboratories.

2. According to the results of the research, among the large-scale high-voltage converters of various types, highvoltage broadband voltage dividers of resistive-capacitive type have the most acceptable characteristics of the accuracy of high voltage conversion in accordance with class A of the International Standard IEC 61000-4-30.

3. Among the main scientific problems of the development of the theory and practice of high-voltage broadband voltage dividers, one should note the influence of the non-identical parameters of the $R, C$ - elements of the high-voltage arm, the matching of the distribution of the potentials of the circuit of lumped $R, C$ - elements and the spatial-field circuit of the divider, as well as the optimal damping of its circuit connections.

4. It is necessary to create high-voltage mobile calibration laboratories for metrological certification of both transformers and voltage dividers with their actual load at the substations.

\section{REFERENCES}

1. GOST 13109-97. Elektricheskaya energiya. Sovmestimost' tehnicheskih sredstv elektromagnitnaya. Normy kachestva elektricheskoi energii v sistemah elektrosnabzheniya obschego naznacheniya [State Standard 13109-97. Electric Energy. Electromagnetic compatibility of technical equipment. Power quality limits to general purpose power systems]. Moscow, IPK Publishing house of standards Publ., 1999. 35 p. (Rus).

2. DSTU IEC 61000-4-30:2010. Elektromahnitna sumisnist'. Chastyna 4-30. Metody vyprobuvannya ta vymiryuvannya. Vymiryuvannya pokaznykiv yakosti elektroenerhiyi [State Standard DSTU IEC 61000-4-30:2010. Electromagnetic compatibility (EMC). Part 4-30. Testing and measurement 
techniques. Power quality measurement methods]. Kyiv, DP «UkrNDNC» Publ., 2016. 49 p. (Ukr).

3. DSTU EN 50160:2014. Kharakterystyky napruhy elektropostachannya $v$ elektrychnykh merezhakh zahal'noyi pryznachenosti [State Standard DSTU EN 50160:2014. Voltage characteristics of electricity supplied by public electricity networks]. Kyiv, Ministry of Economic Development of Ukraine Publ., 2014. 27 p. (Ukr).

4. GOST 32144-2013. Elektricheskaia energiia. Sovmestimost tekhnicheskikh sredstv elektromagnitnaia. Normy kachestva elektricheskoi energii $v$ sistemakh elektrosnabzheniia obshchego naznacheniia [State Standard 32144-2013. Electric Energy. Electromagnetic compatibility of technical equipment. Power quality limits to general purpose power systems]. Moscow, Standartinform Publ., 2014. 16 p. (Rus).

5. ELSPEC LTD. G4K. Fixed Power Quality Analyzer. User \& Installation Guide. 2013. Available at: http://elspec$\underline{\text { Itd.com/download/g4400-user-guide/ }}$ (accessed 26 August 2017).

6. IEC 61000-4-30:2015. Electromagnetic compatibility (EMC). Part 4-30. Testing and measurement techniques. Power quality measurement methods.

7. Muscas C. Power quality monitoring in modern electric distribution systems. IEEE Instrumentation \& Measurement Magazine, 2010, vol.13, no.5, pp. 19-27. doi: 10.1109/MIM.2010.5585070.

8. Pawelek R., Wasiak I. Comparative measurements of voltage harmonics in transmission grid of $400 \mathrm{kV}$. 16th International Conference on Harmonics and Quality of Power $(I C H Q P), \quad 2014, \quad$ pp. 606-610. doi: 10.1109/ICHQP.2014.6842763.

9. Blajszczak G. Resistive voltage divider for higher harmonics measurement in $400 \mathrm{kV}$ network. 11th International Conference on Electrical Power Quality and Utilisation, 2011, pp. 1-4. doi: 10.1109/EPQU.2011.6128953.

10. Harada T., Wakimoto T., Sato S., Saeki M. Development of Japan's national standard class $500 \mathrm{kV}$ lightning impulse voltage divider. IEEE Power Engineering Society Winter Meeting. Conference Proceedings (Cat. No.00CH37077), 2000, vol.3, pp. 1564-1568. doi: 10.1109/PESW.2000.847575

11. Prochazka R., Hlavacek J., Knenicky M., Mahmoud R. Determination of frequency characteristics of high voltage dividers in frequency domain. 17th International Scientific Conference on Electric Power Engineering (EPE), 2016, pp. 14. doi: 10.1109/EPE.2016.7521821.

12. GOST 1516.3. Elektrooborudovanie peremennogo toka na napriazheniia ot 1 do $750 \mathrm{kV}$. Trebovaniia $k$ elektricheskoi prochnosti izoliatsii [State Standard 1516.3. Electrical equipment of alternating current for voltage from 1 to $750 \mathrm{kV}$. Requirements for dielectric strength of insulation]. Moscow, IPK Publishing house of standards Publ., 1998. 50 p. (Rus).
13. Brzhezytskyi V.O., Brzhezytskyi V.V., Isaiev V.V., Kikalo V.M., Lapchenko A.M., Masliuchenko I.M., Trotsenko Ye.O. Mobile verification laboratory of voltage classes $0.22 \ldots 110 \mathrm{kV}$. Metrolohichne zabezpechennya obliku elektrychnoyi enerhiyi: Mater. 6-yi nauk.-prakt. konf. [Materials of the 6th Scientific and Technical Conference «Metrological maintenance of electric energy accounting»]. Kyiv, AVEGA Publ., 2007, pp. 202-204. (Ukr).

14. Bolotin I.B., Eidel L.Z. Izmereniia $v$ perekhodnykh rezhimakh korotkogo zamykaniia [Measurements in transient short-circuit conditions]. Leningrad, Energiya Publ., 1981. 192 p. (Rus).

15. Atarod S., Brzhezytskyi V.O., Garan Ya.O., Masliuchenko I.M., Anokhin Yu.L. Characteristics of high voltage dividers designed for power quality measurement. Scientific Works of National University of Food Technologies, 2013, no.51, pp. 91102. (Ukr)

16. Brzhezytskyi V.O., Desiatov O.M., Masliuchenko I.M., Yatsenko I.S. Frequency characteristics due to the nonidentical $\mathrm{R}, \mathrm{C}$-elements of the high voltage divider for measuring power quality. Scientific Works of National University of Food Technologies, 2017, vol.23, no.1, pp. 158-172. (Ukr).

17. Atarod S. Udoskonalennya vysokovol'tnykh podil'nykiv postiynoyi ta zminnoyi napruhy (chastoty $50 \mathrm{Hts}$ ) Diss. cand. techn. nauk [Improvement of high-voltage dividers direct and alternating voltage (frequency $50 \mathrm{~Hz}$ ). Cand. tech. sci. diss.]. Kyiv, 2014. 134 p. (Rus).

Received 03.11.2017

Y.L. Anokhin ${ }^{1}$, Head of the Research Department of Electrical Quantities Measurement,

V.O. Brzhezytskyi ${ }^{2}$, Doctor of Technical Science, Professor, Ya.O. Haran ${ }^{2}$, Engineer,

I.M. Masliuchenko ${ }^{2}$, Candidate of Technical Science, Associate Professor

O.P. Protsenko ${ }^{2}$, Candidate of Technical Science, Associate

Professor,

Ye.O. Trotsenko ${ }^{2}$, Candidate of Technical Science, Associate

Professor,

${ }^{1}$ State Enterprise «Ukrmetrteststandart»,

4, Metrolohichna Str., Kyiv, Ukraine, 03168 , e-mail: hivolt@ukrcsm.kiev.ua,

phone +380445263485

${ }^{2}$ National Technical University of Ukraine «Igor Sikorsky Kyiv Polytechnic Institute»,

37, Prosp. Peremohy, Kyiv, Ukraine, 03056, e-mail: v.brzhezitskiy@ukr.net, garan.yaroslav@gmail.com, i.masluchenko@gmail.com, apro54@ukr.net, trotsenko@email.ua

phone +380442367989

How to cite this article:

Anokhin Y.L., Brzhezytskyi V.O., Haran Ya.O., Masliuchenko I.M., Protsenko O.P., Trotsenko Ye.O. Application of high voltage dividers for power quality indices measurement. Electrical engineering \& electromechanics, 2017, no.6, pp. 53-59. doi: 10.20998/2074-272X.2017.6.08. 